\title{
The Use of the Country of Origin Information in Communication Strategies Used by Brazilian Cosmetics-Exporting Enterprises in External Markets ${ }^{1}$
}

\author{
Matheus Arantes Paterlini \\ Bachelor in Business Administration by the University of São Paulo, Brazil \\ Av. Bandeirantes, 3900. Ribeirão Preto (SP), Brazil. CEP: 14.040-900 \\ Tel: 55-16-8122-7809Ｅ-mail: matheus.paterlini@gmail.com \\ Janaina de Moura Engracia Giraldi (Corresponding author) \\ Professor Doctor at FEA-RP, University of São Paulo (USP), Brazil \\ Av. Bandeirantes, 3900. Ribeirão Preto (SP), Brazil. CEP: 14.040-900 \\ Tel: 55-16-3602-4970Ｅ-mail: jgiraldi@usp.br \\ Lara Bartocci Liboni Amui \\ Professor Doctor at FEA-RP, University of São Paulo (USP), Brazil \\ Av. Bandeirantes, 3900. Ribeirão Preto (SP), Brazil. CEP: 14.040-900 \\ Tel: 55-16-3602-4484Ｅ-mail: lara.liboni@gmail.com
}

Received: Sep. 13, $2012 \quad$ Accepted: Sep. 27, $2012 \quad$ Published: October 1, 2012

doi:10.5296/jmr.v4i4.2381ＵRL: http://dx.doi.org/10.5296/jmr.v4i4.2381

\begin{abstract}
The objective of this article was to identify the communication strategies that are used by Brazilian cosmetics-exporting enterprises and to determine the use of the country of origin information in these strategies. This exploratory study was conducted through telephone and e-mail interviews with five Brazilian enterprises in the cosmetics sector. Data analysis revealed that these enterprises emphasized the country of origin information mainly through

\footnotetext{
${ }^{1}$ This research had the financial support of the National Council for Scientific and Technological Development (Conselho Nacional de Desenvolvimento Científico e Tecnológico, CNPq).
} 


\section{Macrothink}

Journal of Management Research

ISSN 1941-899X

2012, Vol. 4, No. 4

the use of the "Made in Brazil" label and the Brazilian biodiversity. In the commercialization of their products, enterprises consider the brand to be the most important item. The use of the country of origin in the commercialization of products led to an important discussion on the image of Brazil in this sector. The results and conclusions presented in this manuscript will help cosmetics-exporting enterprises adjust their communication strategies abroad to improve sales.

Keywords: Country image, Country of origin effect, Communication, External markets, Cosmetics 


\section{Introduction}

In recent decades, the rapid globalization of markets has spurred growth in international commerce. One of the most significant effects of the recent movement towards a greater integration of world markets is the reduction in the barriers that limit international commerce and the consequent exposure of enterprises to international competition. As described by Usunier (2002), production has become more internationalized through the combination of diverse production sources for the production of the same final good.

In this more open and globalized business environment, nations are under pressure to develop and commercialize their "national brands" to position themselves favorably on the mental maps of the consumers. In any industry, a positive country image can have an impact on an enterprise's ability to compete in the global market (Chandra, Fealey, \& Rau, 2006).

Therefore, the country of origin can have an important impact through marketing communication strategies and thus behaves as a variable in the consumer's evaluation of products and brands (Verlegh, Steenkamp, \& Meulenberg, 2005). Research has shown that the image that a consumer has of a product and the brand's country of origin influence his/her purchasing behavior (Yasin, Noor, \& Mohamad, 2007). This phenomenon, which is known as the country of origin effect, is therefore a factor that should be considered in the decisions surrounding an organization's marketing activities (Al-Sulaiti \& Baker, 1998, Josiassen \& Harzing, 2008).

Thus, in this context, the image of the country of origin is an important tool that expresses an intangible, emotional component that can affect investment decisions. Numerous academic studies (Agarwal \& Sikri, 1996; Chao \& Rajendran, 1993; Essoussi \& Merunka, 2007; Giraldi \& Lopes, 2012; Jaffe \& Nebenzahl, 2001; Pharr, 2005) have shown that a positive country of origin image influences a consumer's evaluation of the country's products and, as a result, his/her intention to buy those products. Various governments have recognized the important effect that the country of origin image has on the success of their products abroad and thus understand that countries should be treated as brands (Balabanis, Mueller, \& Melewar, 2002).

Given the importance of the "country of origin image", this attribute should receive special attention from decision makers in relation to a country's products and service exportation strategies. Taking into consideration the abovementioned aspects, this article intends to inform marketing practitioners, particularly cosmetics-exporting enterprises, that necessarily use or intend to use communication strategies that emphasize the country of origin. The cosmetics sector was chosen because Brazil occupies the third-place position in the world market of personal hygiene, perfumery and cosmetic products.

The question being researched is the following: which communications strategies are used by Brazilian cosmetic exporting enterprises to highlight the country of origin of their products in external markets? The results of this study will help cosmetics-exporting enterprises to adapt to the international market and to improve their communication techniques and strategies within this market. In addition, this study aims to reveal and underscore the importance of 
providing information on the country of origin, with the goal of amplifying this information and thereby continuing to develop this important area of study in Brazil.

Furthermore, this manuscript also attempts to determine how factors related to the country of origin can influence a consumer's evaluation of a product or service. The results presented in this manuscript can therefore help marketing practitioners better understand the factors that contribute to the formation of the country of origin concept, thus allowing them to better utilize a given product's country of origin as a marketing tool (Balabanis et al., 2002).

This research intends to fill a gap in the country of origin concept through a study of the cosmetics sector's communication strategies in foreign markets. As an empirical study, it is innovative because the information was obtained directly from enterprise export managers. This study is therefore different from other thematic studies in which the information on the influence of the country of origin is collected from the point of view of the consumer. This study intends to improve the understanding of these themes and will therefore not only help marketing practitioners to better elaborate their communication strategies in external markets but will also help researchers to plan future studies in this area.

\section{2. “Country of origin” effect}

The existence of stereotypical attitudes towards foreign products is one of the peculiarities of global marketing (Keegan, 2012) because consumers tend to develop preconceived ideas about products from other countries. According to Verlegh (2007), some studies show strong evidence that the country image actually changes over time and that beliefs about the country of origin are also changeable. The stereotypical attitudes (for example, "Germany is synonymous with engineering quality, Italy is synonymous with fashion, and France is synonymous with chic") can favor or damage the efforts of marketing professionals, as the products produced by a less-developed country are judged under the image of its political-economic situation and not by their intrinsic quality. This phenomenon is known as the "country of origin effect".

Many governments sponsor aggressive export promotion programs to facilitate the entry of enterprises into the international market. These programs provide knowledge on how enterprises can become international (Kotler \& Keller, 2007). In Brazil, the government can position itself to improve Brazil's image in other countries by providing, among other advantages, the infrastructure to improve Brazilian products. Thus, enterprises should research and understand the actual image of its products and, if the image is unfavorable, develop strategies to minimize the negative impact. Among these strategies, the following parameters stand out: the cost of the product, which should be similar to the cost that the consumer is willing the pay; the promotion of a stronger brand; and the establishment of partnerships in the supply chain to generate a better structured, stronger distribution process that can neutralize the product's negative aspects.

Government authorities are able to strengthen the image of their country not only to aid domestic export enterprises but also to attract investors and foreign enterprises. The enterprises are then able to advantageously use the positive perceptions of their country of 
origin to sell more products and services (Kotler \& Keller, 2007). The first step in competing in a unified market consists of understanding the behavior of the global consumer (Craig \& Douglas, 1996). A country's stereotypes can be positive or negative; thus, the use of the country of origin image is an important element in the marketing strategies that are used by enterprises that compete internationally (Al-Sulaiti \& Baker, 1998).

However, it is worth noting that the country of origin is only one of the various criteria that are used in product evaluation. The criteria used by consumers are nothing more than attributes or dimensions that can help evaluate or judge the alternatives of a given purchase. There are numerous evaluation criteria, such as price, brand, safety, country of origin, warranty, and reliability. Other criteria are more subjective, such as the feeling that a consumer has when owning a product (Engel, Blackwell, \& Miniard, 1995).

Jaffe and Nebenzahl (2001) define the country of origin image as the mental perception that people have of a country. For Verlegh and Steenkamp (1999), the country of origin image refers to a mental representation of the people, products, culture, and national symbols of a country. In other words, the inferences that the consumer makes about a country are formed by past associations with the country's beliefs, culture, and symbols. According to Verlegh and Steenkamp (1999), a country's image includes widely shared cultural stereotypes that persist even after consumers actually experience the country's products. Consumers use these stereotypical images of countries to judge products. These images are created from a number of variables, such as national characteristics, economy, history, and traditions (Baker \& Ballington, 2002). Similarly, Jaffe and Nebenzahl (2001) state that the image of a country is influenced by the perceptions that consumers have of the people of that country, the quality of its products, and its level of economic development.

Therefore, the image formed of a given country is the complete perception that consumers have of the country, which is based on the processing of various pieces of information obtained from many different sources over time. According to Chandra et al. (2006), consumers associate positive and negative stereotypes to products and brands originating from different countries. This phenomenon occurs in such a way that these associations can either represent the reality or can result in "illusory associations” and incorrect inferences.

Recent research on country of origin has been shifting from a mere assessment of the product differences and preferences based on a country of origin premise to the analysis of a "more complex construct” - the actual country image (Roth \& Diamantopoulos, 2009). A positive image is associated with consumer loyalty, which makes the consumer favor the promotions of a given product or brand and resist the competition. Similar to the image of an enterprise, a "country of origin image" also evokes certain values, qualifications, and feelings about the product in the mind of the consumer. As in the advertisements of well-established brands, a "country image" includes an established identity as an indicator of the product quality (Anholt, 2000; Baughn \& Yaprak, 1993; Papadopoulos, 2000). Thus, the image of the country of origin directly affects a consumer's evaluations of the products that are produced in that country, thereby leading to the "country of origin effect". 
The country of origin effect has been defined a number of times in the literature. In general, this effect refers to the influence that information on the country of origin has on the attitudes and behaviors of consumers toward a product or a brand. Studies on the country of origin effect have attempted to identify processes that can help explain how the country of origin influences the evaluation of a product (Ayrosa, 2000). According to Pharr (2005), decades of studies on the subject have led to an apparently unequivocal conclusion: the country of origin of a product can influence the consumer judgments of the product such that the product will sell more in international markets if the country of origin effect is positive.

The following consumer characteristics can influence the country of origin effect: level of education, conservatism, age, gender, fluency in the country's native language, familiarity with the product, necessity of cognition, motivation, level of involvement, familiarity with the brand, and cultural background (Anderson \& Cunningham, 1972; Balabanis et al., 2002; Chao \& Rajendran, 1993; Johansson, Douglas, \& Nonaka, 1985; Maheswaran, 1994; Schaefer, 1997; Shimp \& Sharma, 1987; Zhang, 1997).

The country of origin effect in the evaluation of products also varies based on the product category. In addition, economic, social, and cultural systems, as well as the stage of the country's development, represent information that permeates the consumer's mind. These perceptions are based on the complexity of the product, the level of development of the product, the familiarity with the country of origin, and the demographic and socio-psychological characteristics of the country (Kucukemiroglu, Kara, \& Harcar, 2005; Lin, Sternquist, 1994; Maheswaran, 1994; Papadopoulos \& Heslop, 1993; Roth \& Romeo, 1992; Zhang, 1996).

Ethnocentrism, which represents consumers' tendency to value national products more highly than imported products to the detriment of imported products, can also be related to the country of origin effect (Baker \& Michie, 1995; Cleveland, Laroche, \& Papadopoulos, 2009). Several studies have shown that ethnocentrism impacts the purchasing decisions of consumers (Shimp \& Sharma, 1987; Papadopoulos \& Heslop, 1990; Evanschitzky, Wangenhein, Woisetschlaeger, \& Blut, 2008).

However, ethnocentrism can vary according to the psychographic and demographic characteristics of the consumers. For example, older consumers tend to be more conservative, which diminishes the grade of ethnocentrism. In addition, the interaction with other cultures can also reduce consumer preconceptions of imported products (Sharma, Shimp, \& Shin, 1994).

Based on the premise that consumers are influenced by the country of origin effect, countries that possess a positive image should use communication strategies to highlight this information and thus make use of this competitive advantage.

\section{Communication strategies in external markets and the role of the country of origin}

Communication is one of the major tools of marketing because it is the means by which enterprises stimulate sales, motivate and persuade consumers, and improve the image of their brand to the general public, including distributors. Communication allows enterprises to 
connect their brands to people, places, experiences, feelings, and objects (Kotler \& Keller, 2007). The global communication strategy can be standardized, which assumes that all customers have the same desires and necessities, or localized, which occurs when the advertising needs to be adapted depending on the country where it will be implemented (Keegan, 2012).

In the global environment, communication strategies undertake modern approaches to improve and facilitate work, provide entertainment, and increase the quality of life. Therefore, the best strategy is not a matter of opinion but of necessity (Levitt, 1983). The debate between standardized and localized advertising is worth highlighting. According to the argument of standardization, people worldwide want the same products for the same reasons. However, there are those who affirm that consumers differ from country to country; therefore, the requirements for localized advertising are specific to each country (Keegan, 2012). The determination of the best approach depends on a managerial analysis of the aspects involved and on the product to be advertised. A global campaign tends to result in cost savings, the potential of a global creative appeal, and increased control, whereas the localized approach has the advantage of focusing on the main product attributes in each culture or country (Keegan, 2012).

Communication strategies in external markets have certain peculiarities. It is therefore necessary that these aspects be developed together with the country of origin concept. In addition, the main theoretical concepts need to be considered in the development of communication strategies. An important problem that marketing practitioners face in the current competitive market is the selection of the new products and communication strategies that can be implemented with low risk. In the context of international marketing, the country of origin is an important consideration in the communication decisions. The existence of a positive country of origin image provides marketing professionals an easier introduction of new products and faster consumer acceptance (Agarwal \& Sikri, 1996).

Studies have shown that the country of origin image is influenced not only by economic and cultural factors but also by the national identity as an all-encompassing factor. Therefore, an individual enterprise is not capable of controlling its country image (Jaffe \& Nebenzahl, 2001). Niss (1996) suggests that the use of the country image in the promotion of products and services abroad occurs more frequently in the introductory cycle of the "International Product Life Cycle" than in the growth and maturity cycles. In addition to the stage of the product life cycle, Keegan (2012) highlights that it is necessary to consider the strong disparities in the product demands in the different markets: the lower the market saturation index of a product, the greater the level of its acceptance. In other words, it is necessary to research the market saturation to identify potential market opportunities and to consider the disparities in product demand.

Thus, the use of the country image as a marketing tool in the beginning of the international cycle can help exporters penetrate the market faster than they would by investing in a weak and/or not well-known brand (Jaffe \& Nebenzahl, 2001). 
In many countries, including Brazil, the labeling standards demand that enterprises reveal a product's country of origin. This legal requirement has made researchers and marketing professionals interested in understanding the attitudes of consumers toward foreign products (Kotler \& Gertner, 2004). Consumers lend particular attention to the country image when they only have a small amount of information available to evaluate the product. In emerging markets, imports (mainly consisting of products with unknown brands) increase and the information about the countries where the products are produced and designed is not as important. Depending on the product category, the influence will be stronger for public goods (e.g., cars, watches, clothes) that carry symbolic values and weaker for private goods (e.g., televisions, furniture) (Essoussi \& Merunka, 2007).

The marketing strategy used to enter into new markets or countries depends on innumerable variables, including the strength of the brand and its country of origin. There are four possible entry strategies that involve the aspects described above. The first scenario considers enterprises with a strong brand and a positive country image, which is the ideal position for an enterprise. In this case, the country of origin and the brand should both be emphasized, particularly if it is a global brand. The second scenario consists of a weak country image and a strong brand. In this situation, it is necessary to emphasize the brand and de-emphasize the country of origin, manufacturing, and design as much as possible. A third strategy contemplates a scenario in which a positive country image is combined with a weak brand. In this strategy, the enterprise should emphasize the country of origin and de-emphasize the weak brand image. The fourth scenario suggests the neutralization of the brand image and the country of origin, both of which are considered weak and negative. This neutralization can be achieved through a number of strategies, such as price discounts, quality control, and the establishment of a niche market. Thus, the brand can improve over time as long as consumers value the intrinsic characteristics of the product in their purchasing decisions (Jaffe \& Nebenzahl, 2001).

More specifically, organizations should analyze the country image, recognize the capacity of the country image in the design/manufacturing of a category of products, and emphasize the country image in their communication strategy such that the brand can benefit from it. If the country has a negative image or an image that does not recognize the country's competencies, marketing practitioners should establish strategies that reduce the country of origin information such that the consumers base their decisions in other aspects when evaluating the product (Essoussi \& Merunka, 2007).

If the image is positive, there are some strategies that can be used to communicate information about the country of origin, such as using "Made in..." labels, the direct inclusion of the country in the brand or enterprise name (e.g., British Airways, Iberia, which carries the country name), the indirect suggestion of the country through the brand spelling or word derivation (e.g., the brand names Ferrari, Matsushita, Livetti, and Renault suggest the country of origin), and the indication of the country of origin through product package design (e.g., the Australian beer Fosters has a Kangaroo on its label) (Ayrosa, 2000). 
Nevertheless, the emphasis of the country of design (or suggesting it through the brand) has a strong influence in public goods (e.g., cars, watches, clothes) that carry symbolic value and a minor influence on private goods (e.g., televisions, furniture). In turn, the impact of the country of manufacture in the product quality is also highly significant; consumers tend to prefer branded public goods that are planned and produced in specific countries, particularly first-world countries. Due to the negative image of the majority of emerging countries, national enterprises should emphasize the country of design and the country of origin of products unrelated to standard consumption, such as products that use technology that has already been publicized and established (Essoussi \& Merunka, 2007).

Understanding how and when positive associations can be transferred through "Made in..." labels (developed for well-known products) to other products would generate an increase in the supply of the products that are targeted by marketing practitioners and in the development of new marketing strategies (Agarwal \& Sikri, 1996).

The country of origin image can influence the purchasing behavior of consumers. Thus, through well-established communication strategies, the country of origin image may become an important marketing tool that can help enterprises adjust their communication strategies in external markets.

\section{Methods of empirical research}

The present exploratory study, which was conducted through phone and e-mail interviews, aims to identify the communication strategies that are used by Brazilian cosmetic exporting companies and determine which of these involve the country of origin. Thus, this study aims to identify the characteristics of this phenomenon and ascertain some explanations for its causes and consequences (Richardson, 1989). The use of an exploratory study is, therefore, the most appropriate because this type of study offers a global view, and it is generally performed when little information is available on the study subject. The use of interviews was necessary given the inherently high level of flexibility of this methodology and their suitability to situations in which no other sources of information are available (Richardson, 1989).

The target population of the present study included enterprises in the cosmetics sector, including all of the enterprises that form part of the Brazilian Beauty group (an integrated sectoral project for the commercialization of exports), which is organized by the Brazilian Association of the Cosmetics, Toiletry and Perfumery Industry (Associação Brasileira da Indústria de Higiene Pessoal, Perfumaria e Cosméticos - ABIHPEC) in partnership with the Brazilian Trade and Investment Promotion Agency (Agência de Promoção de Exportação e Investimentos - APEX). The consortium, which is composed of 72 enterprises, was chosen to represent this population of enterprises because it is formed by the ABIHPEC, which represents, on the national and international level, all the enterprises that are related to the promotion, manufacturing and commercialization of products intended for personal care. The initial goal was to contact all the consortium's member enterprises. However, due to refusals and other related roadblocks to data gathering, a non-probabilistic sample of these enterprises 


\section{Macrothink}

Journal of Management Research

ISSN 1941-899X

2012, Vol. 4, No. 4

was used. In-depth interviews with the managers of the export departments of five different enterprises were carried out in 2009.

Propositions are used in qualitative analyses, and they can be defined, when they refer to an observable phenomenon, as a statement about concepts that can be judged as true or false (Cooper \& Schindler, 2000). The main proposition of this exploratory research was that the image of Brazil affects the communication strategies used by its cosmetics-exporting enterprises in the external market.

To verify this proposition, a list of relevant questions, which were presented to the export managers of the enterprises listed in the ABIHPEC/APEX project, was generated. These questions were categorized into eleven sets of questions, as shown in Table 1 . The questions were developed based on the main theoretical presuppositions in the study and were designed to verify the results attained and to identify the hurdles that limit the more effective use of the country of origin information. 
Table 1. Interview questions

\begin{tabular}{|c|c|}
\hline Question & Details \\
\hline 1 & What products do you export? To which countries do you export? \\
\hline 2 & $\begin{array}{l}\text { Who are your main international competitors (in each country)? Do your } \\
\text { competitors display their respective countries? Are they successful? }\end{array}$ \\
\hline 3 & Do you emphasize the country of origin information in your products? \\
\hline 4 & $\begin{array}{l}\text { If country of origin is emphasized, in what form is this performed? Do you use } \\
\text { specific colors on the label that indicate the country of origin? Do you use the } \\
\text { label "Made in Brazil"? Does the name of the product show its Brazilian } \\
\text { origin? Do you use sounds, slogans, or pictures? }\end{array}$ \\
\hline 5 & $\begin{array}{l}\text { Is the use of Brazilian biodiversity effective in highlighting the country of } \\
\text { origin? What other elements related to Brazilian culture, climate, or country } \\
\text { characteristics can be used? }\end{array}$ \\
\hline 6 & $\begin{array}{l}\text { Do you always provide information on the country of origin or do you stop } \\
\text { using this information once the product gains a market? }\end{array}$ \\
\hline 7 & $\begin{array}{l}\text { What is the importance of the brand in the commercialization of a product? Is } \\
\text { your brand well-known and strong? Is your brand stronger and more positive } \\
\text { than the image of Brazil? }\end{array}$ \\
\hline 8 & $\begin{array}{l}\text { In international competition, what advantages and disadvantages does the use } \\
\text { of the label "Made in Brazil" have? }\end{array}$ \\
\hline 9 & $\begin{array}{l}\text { What changes in the image that buyers have of Brazil could make the strategy } \\
\text { of using the country of origin in the promotion of Brazilian cosmetics more } \\
\text { successful? }\end{array}$ \\
\hline 10 & $\begin{array}{l}\text { How can the Brazilian government promote an improvement in its country } \\
\text { image to positively influence the sale of Brazilian products in external } \\
\text { markets? }\end{array}$ \\
\hline 11 & $\begin{array}{l}\text { What can the sector's exporters do to improve the country image to ultimately } \\
\text { influence the sale of Brazilian products in external markets? }\end{array}$ \\
\hline
\end{tabular}

The responses to these questions were analyzed through content-analysis, which is a data treatment technique that aims to identify what is being said on a given theme. The analytical categories used in this research were the following: the use of information related to the country of origin of exported products, the use of biodiversity, the advantages and disadvantages observed from the use of the label "Made in Brazil", the change that should occur in the image that buyers have of Brazil, and the actions that the Brazilian government can promote to improve the country image. 


\subsection{The cosmetics sector}

The cosmetics industry first appeared due to developments in biochemistry. The activities of this industry are linked with the manipulation of formulas to design products that are can be safely applied to the human body to clean, beautify, or alter an individual's appearance without affecting its structure or functions (Salomao, Guerrero, \& Garcia, 2008). It is a sector that constantly invests in the release and promotion of new products and in the renovation and maintenance of the outstanding attributes of its formulas to improve the consumer's appearance.

The cosmetics sector should be defined according to the use of its main products. According to the definition detailed by ANVISA (Agência Nacional de Vigilância Sanitária, 2009) in resolution 92, this sector is defined as the following: "the products of personal hygiene, cosmetics, and perfumes are preparations that are composed of natural or synthetic substances for external use on diverse parts of the human body [...] with the exclusive or main objective of cleaning, perfuming, altering the appearance, and/or protecting or maintaining the body in good condition”.

The definition includes, among other cosmetic products, the products of perfumery and personal hygiene: skin creams, lotions, talc powders and sprays, perfumes, lipsticks, nail polish, facial and eye make-up, hair dyes, liquids for perms, deodorants, children's products, oils, bath foams, and mouthwashes (Salomao et al., 2008).

According to the BBC Brasil (2007), executives from the industry state that Brazilian products are considered products that are more pure than those originating from other parts of the world. In addition, the statement "Brazilians have an image of a healthy and attractive people” also influences the acceptance of Brazilian products abroad. Moreover, the historic fact of the miscegenation of people from distinct origins has helped the development of this sector. Because the Brazilian mix of people has resulted in various body forms, skin tones, and hair types, the manufacturers of beauty products were forced to produce products that satisfy all of these consumers. Therefore, these companies will have an appropriate product for any consumer, regardless of the target market abroad (BBC Brasil, 2007).

The growing participation of women in the labor market, the cutting-edge technology, and the resultant increase in productivity are only some of the factors that should be considered in the analysis of the excellent growth of this sector. Furthermore, the increase in the life expectancy of the population has translated to a necessity for preserving the impression of youth, which further favors the sale of cosmetics (ABIHPEC, 2010).

In the national and international environments, there is an entity that represents the enterprises that are related to the promotion, manufacturing, and commercialization of finished products designated for personal care. This entity is known as ABIHPEC (the initials (in Portuguese) stand for the Brazilian Association of the Cosmetic, Toiletry and Fragrance Industry). Its foreign trade component coordinates the activities of the ABIHPEC/APEX sectoral project for the commercialization and promotion of exports. 
This project aids enterprises in diverse actions of export promotion, such as business roundtables, international fairs, missions, and collective catalogs focused on exportation. One of the main advantages offered by the project, in addition to cost reduction, is the exchange of past experiences among the participating enterprises to reduce barriers, thus facilitating the access of newer enterprises and products to the international market.

According to the manager of Apex-Brazil, entrepreneurs must know, in addition to manufacturing, who their competitors are, how foreign markets operate, and the regulatory compliances that they must adhere to, such as sanitation regulations. Brazilian cosmetic enterprises need an identity, but they also need to be adapted to the countries that they want to enter (InfoMoney, 2009).

The use of Brazilian biodiversity in the formulation of products gives this national industry its identity. The fact that Brazil has approximately $20 \%$ of the planet's biodiversity makes it the owner of a rich flora with a great variety of seeds, aromatic roots, herbs, and plants. Many have exotic names and produce natural cosmetics; this is particularly true with the active ingredients from plants of the Amazon rainforest. These elements have a great marketing appeal abroad, which opens the doors for the export of these products.

According to the BBC (2007), the Brazilian cosmetics industry uses its nationality to promote sales abroad. This strategy has had positive results, particularly with Amazonian essences. The exotic names of fruits, barks, seeds, and plants from the Amazon, such as açaí, cupuaçu, and buriti, exhibit ecologic appeal. These names are stamped on bottles of perfume, shampoos, and creams and on boxes of hair dye, thereby separating the Brazilian national industry from the competitive external market.

Among the exported products in 2007, Brazilian products were sold in 135 countries, including Russia, Cuba, and Angola, which were in the initial phase of opening their markets to these products. In addition, Brazil exported $66.1 \%$ of its external sales (close to US\$ 355 million) to other South American countries, which have consistently been the main Brazilian market. This sales volume represents a significant improvement compared to the US\$ 140.4 million that was generated in 2003; the recovery of the Argentine economy was one of the factors that contributed to this improvement (ABIHPEC, 2010).

Given that the total value of all beauty product sales in the Middle East in 2008 was more than US\$ 2 billion, the cosmetics sector will continue to focus on Arab markets. In the United Arab Emirates alone, the beauty and spa markets generate more than US\$ 600 million for the cosmetics industries. The United States occupies first place among the countries that import cosmetics (not restricted to those of Brazilian origin), and it is a market that generates close to US\$ 5 billion. Russia, which is growing in its consumption of cosmetics, has a market of approximately US\$ 2.3 billion and occupies fourth place (InfoMoney, 2009).

Brazil has a large amount of potential raw materials as a result of its large investment in research and development. In addition, Brazil has an extensive line of natural products that exhibit great acceptance abroad. It is therefore clear, given its relevance to the external market and its strong and consistent growth, that an exploratory study with these 
cosmetics-exporting enterprises is important. The study results are described in the next section.

\section{Results}

The research began in March of 2009, after the identification of the participating enterprises that form part of the APEX project, which is composed of 72 enterprises. Some enterprises were excluded due to communications difficulties during the process and/or because they were not suitable in terms of the research profile. One challenge was the number of enterprises that were listed as new participants in the project; these enterprises were therefore still learning the principles of the cosmetics export process. In addition, although they did have the necessary profile, two enterprises refused to formally participate in the study for the following reasons: "we cannot supply confidential data" and "we do not respond to individual research requests”.

A total of five enterprises participated in the qualitative study, which is considered adequate for an exploratory study that does not have the intent of generalizing the results. Some of the reasons that were given by the enterprises that refused to participate in the study were the following: (1) “...we only place the phrase "Made in Brazil” on the label because it is required by law; however, our product appeal is based on the Disney characters that we license, and it therefore does not make sense to overlap these marketing appeals”; (2) “... we do not have communication strategies that are specific to the external market. Our exportation occurs through networking in fairs that occur here in Brazil; in other words, we disseminate products in national fairs and create relationships that take our products to external markets"; (3) "... our strength is fragrances that do not necessarily refer to Brazil as the country of origin...”; and (4) “...I believe that we do not fit the profile of enterprises that you are looking for because our exports have been sporadic until now”.

\subsection{Description of enterprises that participated in the study}

The products exported by the enterprises included in the study fit into ANVISA's (2008) definition of cosmetics. The main products cited by the enterprises are the following: shampoos, conditioners, hair relaxers and masks, gels, nail polish, body lotions, moisturizing creams, hair creams, liquid soaps, and deodorants.

The countries that these enterprises export to are the main countries that most frequently order cosmetics from Brazil, such as the countries of South America, including Chile, Paraguay, Uruguay, Argentina, Bolivia, Peru, Venezuela, and Colombia. Other countries that were often cited include the United States, which is historically the number one importer of cosmetics worldwide (not restricted to cosmetics of Brazilian origin). Russia and Angola were also cited, both of which were in the phase of opening their markets to cosmetic products when the study was conducted. It is also worth noting that the countries of the Middle East, including Saudi Arabia, Yemen, Syria, Lebanon, the United Arab Emirates, Oman, Kuwait, Pakistan, Iraq, and Bahrain, were a large focus of the cosmetics export in 2009, which confirms their strong participation as importers (according to a report by the Brazil-Arab News Agency - ANBA (Agência de Notícias Brasil-Árabe, 2009). 
Other countries that were cited are part of Central America, such as Mexico, Costa Rica, Suriname, and Guatemala. The main European countries, including Portugal, Spain, England, France, Netherlands, Bulgaria, Poland, and Greece, also appear in the list. In addition, although these are not the main importers of Brazilian cosmetics, Japan and African countries, including Mozambique, Libya, Egypt, Ethiopia, Djibouti, Tanzania, Cape Verde, Kenya, and South Africa, were also cited. Thus, a diverse range of cosmetics-importing countries, including both strong and weak importers, exists. Because Brazil has a lot of potential natural resources, its extensive line of natural products has notable acceptance abroad.

The participating enterprises stated that they do not have direct competitors that originate from the national market because their main competitors are multinationals that are involved in cosmetics sales. The next section describes the analysis of the results and will relate these results to the general objective of this study.

\subsection{Presentation and analysis of results}

Regarding the use of the country of origin information in the export of products, three of the enterprises interviewed responded that they emphasize the country of origin information in a positive way. In addition, one of these three enterprises reported that its products are made with ingredients from the Amazon. Therefore, there were two enterprises that reported that they do not emphasize the country of origin information; one of these two companies reported that the product that is available in the internal market is the same product that is exported.

The enterprises that emphasize the country of origin use the "Made in Brazil" label. One of the enterprises sometimes includes the Brazilian flag in the product's label. The enterprises that do not emphasize the country of origin reported that their products are related to fashion and beauty, which are aspects that, according to these enterprises, "induce consumption"; this consumption is not observed when the country of origin is emphasized. The participating enterprises that reported using the "Made in Brazil" label primarily use it because of the labeling requirements that are stipulated by law. These requirements demand that enterprises reveal the place of origin of their products, which is generally found in the back of the packaging.

Only two enterprises reported the use of the Brazilian biodiversity to emphasize the country of origin. However, one of these enterprises highlighted that technology should be more disseminated and emphasized. This enterprise also reported that the technology used in the product adds more value to Brazilian cosmetics. The other enterprise reported that an appeal to biodiversity is more often used in publicity materials.

The other interviewed enterprises reported that they did not utilize biodiversity as a communication strategy in international marketing. One of these reported using the Brazilian women's beauty because consumers, according to the enterprise, “... are always seeking new and alternative beauty products”.

Even if an enterprise does not highlight the country of origin in their communication strategies in external markets, the label should still contain "Made in Brazil" because it is a 
legal requirement. However, according to one of the enterprises, the country of origin information "is still used when the product gains market share; in fact, the use of the country of origin information is reinforced even more at this time". This statement reflects the hypothesis presented by Agarwal and Sikri (1996), who stated that in the context of international marketing, it is important to use of the country of origin in the selection of communication strategies because this information allows for the quicker introduction of new products.

However, the previously mentioned statement contradicts one made by Niss (1996), who suggests that the use of the country of origin image to promote products and services abroad is more frequent in the introductory cycle of the international product cycle of life than during the growth and maturity cycles. Niss's statement is therefore the opposite of the statement made by one of the enterprises, which stated that the country of origin information is reinforced as the product gains more market shares.

The interviewed enterprises also noted the importance of the brand in the commercialization of their products not only to consolidate the quality of their products but also to increase customer loyalty. One of the enterprises even stated that its brand is better known and stronger than Brazil's image. It is worth noting that according to Jaffe and Nebenzahl (2001), the use of the country of origin image as a marketing tool in the beginning of the international cycle helps an exporter penetrate the market faster than by investing in the brand itself if the brand is not strong and well-known. However, the interviewed enterprises prefer to invest more in the promotion of their own brand than in the "country of origin image”.

Most of the enterprises reported that the label "Made in Brazil" exhibited no advantages and/or disadvantages in international competition. One of the enterprises reported that the best advantage is the expected product quality. However, one of the enterprises did report that there are some advantages, particularly "... in relation with the great biodiversity that exists in Brazil, as well as the cultural mix". Other enterprises reported that the “...advantage of using a slogan is that the product can have its origin identified in another country, whether due to consumer curiosity or law requirements”.

The responses to the question "what changes in the image that consumers have of Brazil could make the strategy of using the country of origin in the communication of cosmetics more successful” showed that enterprises think that consumers believe that products from Brazil should be less expensive than products from other countries. One enterprise stated "we are strong and we supply quality products with a high value added...so we should have a premium price". That statement is related to the country of origin effect because, according to Baker and Ballington (2002), the country of origin image includes widely shared cultural stereotypes that persist even after consumers experience a country's products. Consumers suffer that effect because they use stereotypical images of countries to judge foreign products.

Given the existence of stereotypical attitudes toward foreign countries, consumers tend to develop preconceptions regarding products from other countries (Keegan, 2012). The stereotypical attitudes, therefore, can either favor or harm the efforts of marketing 
professionals. Based on the responses provided by one of the enterprises, consumers do not consider Brazil to be a strong country that produces high-quality and high value-added products. Consumers believe, therefore, that products from Brazil should be less expensive. This attitude directly contradicts the reality of exported products, which, according to one of the interviewed enterprises, should have a "premium" price.

Although many governments have already recognized the importance of country image in the success of their products abroad and have realized that the countries should be treated as brands (Balabanis et al., 2002), the interviewed enterprises believe that the Brazilian Government should improve the country image to positively influence sales in external markets. The interviewed enterprises suggested that possible actions should include the creation of financial incentive programs, such as through the lowering of taxes on exported products (thus facilitating sales channels), and the fighting of piracy, which would help avoid a loss in market share. These issues, among others, represent characteristics of the image of Brazil abroad, as well as the difficulties and costs that exporting enterprises face. We hope that the Brazilian government can work toward solving these issues to improve the image of the country.

As was observed in the theoretical review, many governments sponsor aggressive promotion and export programs to facilitate the entry of enterprises into the international market. These programs demand a deeper understanding of how enterprises can promote their own internationalization (Kotler \& Keller, 2007). It is thus necessary for the Brazilian government to recognize the importance of these programs and to help its enterprises successfully enter the international market.

According to Kotler and Keller (2007), enterprises use perceptions of the country of origin in the most advantageous way possible to sell their products and services. In that sense, according to the interviewed enterprises, exporters of the sector should "take advantage of opportunities", "promote major events around the world", and prepare themselves for the market to "gain the image of an enterprise committed to sales and delivery". These actions should all be performed to promote an improvement in the country image and to ultimately positively influence sales in external markets. In addition, one of the enterprises noted that "an investment in the production to meet the demands of the international market", the suitability of products for export, and the quality of the workmanship are the main tools that can be used to improve the country image and positively influence sales abroad. Table 2 presents a summary of the study results. 
Table 2. Summary of the results

\begin{tabular}{|c|c|c|}
\hline $\begin{array}{l}\text { Analytical } \\
\text { categories }\end{array}$ & Results & Conclusions \\
\hline $\begin{array}{l}\text { The use of } \\
\text { information related } \\
\text { to the country of } \\
\text { origin of exported } \\
\text { products }\end{array}$ & $\begin{array}{l}\text { - } 3 \text { of the enterprises emphasize the country } \\
\text { of origin information in a positive way; } \\
\text { - } 1 \text { of these three reported that its products } \\
\text { are made with ingredients from the Amazon; } \\
\text { - } 2 \text { of the enterprises do not emphasize the } \\
\text { country of origin information. }\end{array}$ & $\begin{array}{l}\text { - "Made in Brazil" label is the main tool } \\
\text { used to identify the country of origin of } \\
\text { exported products; } \\
\text { - The label is used as a result of a legal } \\
\text { requirement; } \\
\text { - The label "Made in Brazil" is not directly } \\
\text { linked to communication and marketing } \\
\text { strategies. }\end{array}$ \\
\hline $\begin{array}{l}\text { The use of } \\
\text { biodiversity }\end{array}$ & $\begin{array}{l}\text { - } 2 \text { enterprises reported the use of the } \\
\text { Brazilian biodiversity to emphasize the } \\
\text { country of origin; } \\
\text { - } 1 \text { of these two highlighted that technology } \\
\text { should be more disseminated and } \\
\text { emphasized, adding more value to Brazilian } \\
\text { cosmetics; } \\
\text { - } 3 \text { enterprises do not utilize biodiversity as a } \\
\text { communication strategy in international } \\
\text { marketing; } \\
\text { - } 1 \text { of these highlighted the use of new and } \\
\text { alternative beauty products, not necessarily } \\
\text { linked to biodiversity. }\end{array}$ & $\begin{array}{l}\text { - Biodiversity and its cultural mix help } \\
\text { maintain a favorable country image for } \\
\text { cosmetics with Amazonian origins; } \\
\text { - Enterprises consider the brand more } \\
\text { important than the country image in the } \\
\text { product commercialization. }\end{array}$ \\
\hline $\begin{array}{l}\text { The advantages and } \\
\text { disadvantages } \\
\text { observed from the } \\
\text { use of the label } \\
\text { "Made in Brazil" }\end{array}$ & $\begin{array}{l}\text { - Enterprises confirm the advantages, } \\
\text { particularly in relation with the great } \\
\text { biodiversity that exists in Brazil, as well as } \\
\text { the cultural mix; } \\
\text { - Enterprises confirm the advantage of using } \\
\text { the slogan to have the origin of the product } \\
\text { identified due to consumer curiosity; } \\
\text { - } 1 \text { enterprise reported that the product } \\
\text { quality is a better advantage than the label of } \\
\text { country origin. }\end{array}$ & $\begin{array}{l}\text { - Biodiversity and its cultural mix help } \\
\text { maintain a favorable country image; } \\
\text { - Consumer identify Brazil as a developing } \\
\text { country with low quality and low prices. }\end{array}$ \\
\hline $\begin{array}{l}\text { The change that } \\
\text { should occur in the } \\
\text { image that buyers } \\
\text { have of Brazil }\end{array}$ & $\begin{array}{l}\text { - Cultural stereotypes that persist even after } \\
\text { consumers experience a country's products; } \\
\text { - Consumers do not consider Brazil to be a } \\
\text { strong country that produces high-quality } \\
\text { and high value-added products; } \\
\text { - Products from Brazil should be less } \\
\text { expensive. }\end{array}$ & $\begin{array}{l}\text { - Consumers should identify Brazil as a } \\
\text { country of excellence in product quality } \\
\text { and as a country that has the capacity to } \\
\text { establish a "premium" price. }\end{array}$ \\
\hline $\begin{array}{l}\text { The actions that the } \\
\text { Brazilian } \\
\text { government can } \\
\text { promote to improve } \\
\text { the country image }\end{array}$ & $\begin{array}{l}\text { - Financial incentive programs; } \\
\text { - Lowering of taxes on exported products } \\
\text { (thus facilitating sales channels); } \\
\text { - Fighting of piracy. }\end{array}$ & $\begin{array}{l}\text { - Government and related entities, as well } \\
\text { as the exporters themselves, attempt to } \\
\text { establish a more positive country image; } \\
\text { - Positive country image could be } \\
\text { emphasized more in the communication } \\
\text { strategies used in external markets through } \\
\text { incentive programs. }\end{array}$ \\
\hline
\end{tabular}

\section{Final considerations}

This study analyzed the use of the country of origin information in the communication strategies used by Brazilian cosmetics exporting enterprises. The problem researched 
involved identifying the communication strategies used by Brazilian cosmetics-exporting enterprises to emphasize the country of origin of their products in external markets. Figure 1 presents the main conclusions.

It was observed that the "Made in Brazil" label is the main tool used to identify the country of origin of exported products. However, this label is used as a result of a legal requirement that states that the country of origin must be identified on packaging labels. Thus, the label "Made in Brazil" is not directly linked to communication and marketing strategies. However, Brazil's biodiversity and its cultural mix help maintain a favorable country image for cosmetics with Amazonian origins. It is worth noting, however, that enterprises consider the brand more important than the country image in the product commercialization.

According to the participating enterprises, it is necessary that consumers identify Brazil as a country of excellence in product quality and as a country that has the capacity to establish a "premium" price such that the country of origin effect is more positive. However, this is not the reality because consumers tend to believe that developing countries should sell their products at lower prices and that the products from developing countries are of inferior quality.

It is therefore suggested that the enterprises should analyze the country image in detail and recognize the capacity of the country within a product category, such as the cosmetics sector. If it is shown that the country has a negative image or an image that does not correlate with its competencies, which seems to be the case with the "Made in Brazil" label and Brazil's biodiversity because these are not the principal appeals that favor sales in external markets, marketing practitioners should establish strategies that reduce the country of origin information so that consumers base their evaluation of the product on other aspects.

According to Jaffe and Nebenzahl (2001), it is necessary to reinforce the brand (if it is strong); deconstruct the association of the country of origin, i.e., neutralize the country image; and strengthen all the other aspects that make the consumer better evaluate the benefits of the product or service. It is worth noting that although Brazil's biodiversity helps build a positive image, the image of a developing country appears to overcome this effect, thus making it difficult for enterprises to appeal to the country image in their communication strategies.

Brazil can have its image strengthened if the government and related entities, as well as the exporters themselves, attempt to establish a more positive country image. A positive country image could be emphasized more in the communication strategies used in external markets through incentive programs, reduction of barriers, and events that disseminate the positive country image. A positive country image could therefore significantly increase sales abroad through the appeal of "Brazilianness".

The research limitations of this study should also be emphasized. For example, the number of respondent enterprises and the level of detail in the answers that were received made the generalization of the results difficult. Further in-depth case studies with enterprises should be conducted to obtain more detailed responses that better describe the communication strategies 
that are used in external markets to ultimately aid marketing practitioners in the development of better communication strategies that involve country of origin information.

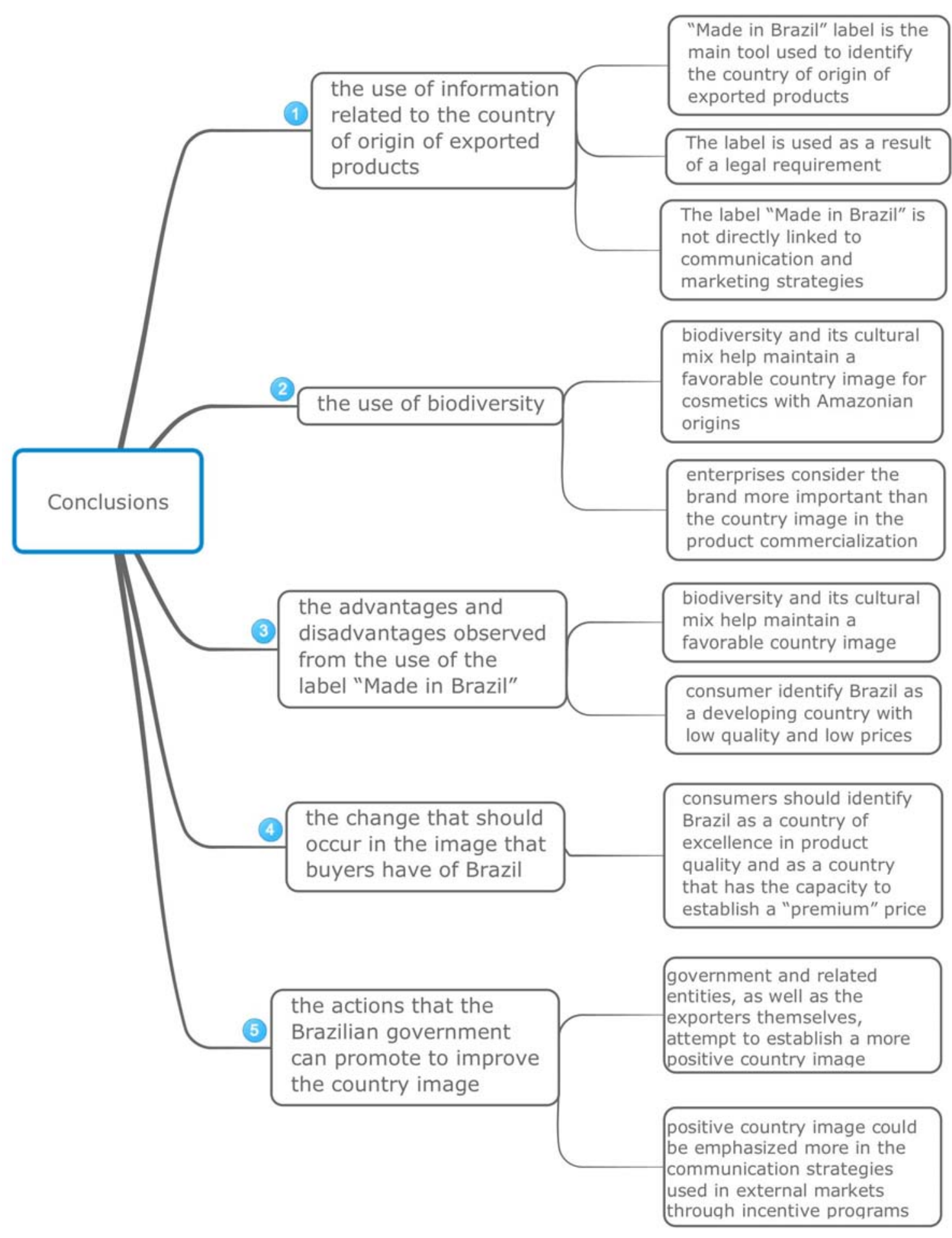

Figure 1. Main conclusions 


\section{References}

Associação Brasileira da Indústria de Higiene Pessoal, Perfumaria e Cosméticos. (2010). Panorama do setor: Higiene pessoal, perfumaria e cosméticos. Retrieved August 10, 2010, from

http://www.abihpec.org.br/wp-content/uploads/2010/11/Microsoft-Word-Panorama-do-setor2010-2011-14_04_2011.pdf.

Agarwal, S., \& Sikri, S. (1996). Country image: Consumer evaluation of product category extensions. Internacional Marketing Review, 13(4), 23-39. http://dx.doi.org/10.1108/02651339610127239

Agência de Notícias Brasil-Árabe. (2009). Indústria de cosméticos cresce mais que o PIB. Retrieved from http://www.anba.com.br/noticia_industria.kmf?cod=8599334

Al-Sulaiti, K., \& Baker, M. J. (1998). Country of origin effects: A literature review. Marketing Intelligence \& Planning, 16, 150-199. http://dx.doi.org/10.1108/02634509810217309

Anderson, W. T., \& Cunningham, W. H. (1972). Gauging foreign product promotion. Journal of Advertising Research, 12(1), 29-34.

Anholt, S. (2000). The nation as brand. Across the Board, 37, 22-28.

Agência Nacional de Vigilância Sanitária. Legislação em vigilância sanitária. Retrieved January 06, 2009, from http://e-legis.anvisa.gov.br/leisref/public/showAct.php?id=34542

Ayrosa, E. A. T. (2000). Some notes on the development of research on country-of-origin effects. Arché Interdisciplinar, (26), 181-214.

Baker, M. J., \& Ballington, L. (2002). Country of origin as a source of competitive advantage. Journal of Strategic Marketing, 10, 157-168. http://dx.doi.org/10.1080/09652540210125297

Baker, M. J., \& Michie, J. (1995). Product country images: Perceptions of Asian Cars. Working Paper Series No. 95/3, Department of Marketing, University of Strathclyde, Glasgow.

Balabanis, G., Mueller, R., \& Melewar, T. C. (2002). The human values' lenses of country of origin images. International Marketing Review, 19, 582-610. http://dx.doi.org/10.1108/02651330210451935

Baughn, C. C., \& Yaprak, A. (1993). Mapping country-of-origin research: Recent developments and emerging avenues. In N. Papadopoulos \& L. A. Heslop (Eds.), Product-century images impact and role in international marketing (pp. 89-116). New York: International Business Press.

BBC Brasil. (2007). Brasilidade eleva vendas de produtos de beleza, diz NYT. Folha Online. Retrieved August 27, 2007, from http://www1.folha.uol.com.br/folha/bbc/ult272u322695.shtml 
Chandra, A., Fealey, T., \& Rau, P. (2006). National barriers to global competitiveness: The case of the it industry in India. Competitiveness Review, 16, 12-19. http://dx.doi.org/10.1108/10595420610760725

Chao, P., \& Rajendran, K. N. (1993). Consumer profiles and perceptions: Country-of-origin $\begin{array}{lllll}\text { effects. } & \text { International } & \text { Marketing }\end{array}$ http://dx.doi.org/10.1108/02651339310032534

Cleveland, M., Laroche, M., \& Papadopoulos, N. (2009). Cosmopolitanism, consumer ethnocentrism, and materialism: An eight country study of antecedents and outcomes. Journal of International Marketing, 17(1), 116-124. http://dx.doi.org/10.1509/jimk.17.1.116

Cooper, D. R., \& Schindler, P. S. (2000). Business research methods. Irwin: McGraw-Hill.

Craig, C. S., \& Douglas, S. P. (1996). Responding to the challenges of global markets: Change, complexity, competition and conscience. Columbia Journal of World Business, 31, 6-18. http://dx.doi.org/10.1016/S0022-5428(96)90028-9

Engel, J. F., Blackwell, R. D., \& Miniard, P. W. (1995). Consumer Behavior (8th ed.). Orlando: The Dryden Press.

Essoussi, L. H., \& Merunka, D. (2007). Consumers' product evaluations in emerging markets. Does country of design, country of manufacture, or brand image matter? International Marketing Review, 24, 409-426. http://dx.doi.org/10.1108/02651330710760991

Evanschitzky, H., Wangenhein, F., Woisetschlaeger, D., \& Blut, M. (2008). Consumer ethnocentrism in the German market. International Marketing Review, 25, 7-12. http://dx.doi.org/10.1108/02651330810851863

Giraldi, M. E., \& Lopes, I. B. (2012). The country of origin effect for Brazilian fresh fruits: A study using Partial Least Squares Procedures. Journal of Management Research, 4(4), 18-38. http://dx.doi.org/10.5296/jmr.v4i4.2062

InfoMoney. (2009). Gestor da Apex dá a fórmula para exportação de cosméticos brasileiros. Empreendedor. Retrieved December 10, 2009, from http://empreendedor.com.br/pt-br/categorias/varejo/artigos/gestor-da-apex-da-a-formula-para -exportacao-de-cosmeticos-brasileiros

Jaffe, E. D., \& Nebenzahl, I. D. (2001). National image and competitive advantage: The theory and practice of country-of-origin effect. Copenhagen: Copenhagen Business School Press.

Johansson, J. K., Douglas, S. P., \& Nonaka, I. (1985). Assessing the impact of country of origin on product evaluations: A new methodological perspective. Journal of Marketing Research, 22, 388-396.

Josiassen, J., \& Harzing, A. (2008). Descending from the ivory tower: Reflections on the relevance and future of country-of-origin research. European Management Review, 5, 264-271. http://dx.doi.org/10.1057/emr.2008.19 
Keegan, W. J. (2012). Global marketing (7th ed.). Upper Saddle River: Prentice Hall.

Kotler, P., \& Gertner, D. (2004). O marketing estratégico de lugares. HSM Management, 44. $\begin{array}{llll}\text { Retrieved } \quad \text { September 20, from } & \text { 2012, }\end{array}$ http://www.hsm.com.br/revista/o-marketing-estrategico-de-lugares

Kotler, P., \& Keller, K. L. (2007). Marketing management. Upper Saddle River: Pearson Learning Solutions.

Kucukemiroglu, O., Kara, A., \& Harcar, T. (2005). Exploring buyer life-style dimensions and ethnocentrism among Canadian consumers: An empirical study. The Business Review, 4(1), 210-217.

Levitt, T. (1983). The globalization of markets. Harvard Business Review, 61(3), 92-102.

Lin, L., \& Sternquist, B. (1994). Taiwanese consumers' perceptions of product information cues: Country of origin and store prestige. European Journal of Marketing, 28(1), 5-18. http://dx.doi.org/10.1108/03090569410049163

Maheswaran, D. (1994). Country-of-origin as a stereotype: Effects of consumer expertise and attribute strength on product evaluations. Journal of Consumer Research, 21, 354-365. http://dx.doi.org/10.1086/209403

Niss, H. (1996). Country of origin marketing over the product life cycle: A Danish case study. European Journal of Marketing, 30(3), 6-22. http://dx.doi.org/10.1108/03090569610107409

Papadopoulos, N. (2000). Countries as brands. Ivey Business Journal, 65, 30-37.

Papadopoulos, N., \& Heslop, L. (1990). A comparative image analysis of domestic versus imported products. International Journal of Research in Marketing, 7, 283-294. http://dx.doi.org/10.1016/0167-8116(90)90005-8

Papadopoulos, N., \& Heslop, L. A. (1993). Product-country images: Impact and role in international marketing. New York: International Business Press.

Pharr, J. M. (2005). Synthesizing country-of-origin research from the last decade: Is the concept still salient in an era of global brands? Journal of Marketing Theory and Practice, 13(4), 34-45.

Richardson, R. et al. (1989). Pesquisa social: Métodos e técnicas. São Paulo: Atlas.

Roth, M. S., \& Diamantopoulos, A. (2009). Advancing the country image construct. Journal of Business Research, 62, 726-740. http://dx.doi.org/10.1016/j.jbusres.2008.05.014

Roth, M. S., \& Romeo, J. B. (1992). Matching product category and country image perceptions: A framework for managing country-of-origin effects. Journal of International Business Studies, 23, 477-497. http://dx.doi.org/10.1057/palgrave.jibs.8490276

Salomao, S., Guerreiro, A. \& Garcia, R. (2008). Setor de cosméticos: indústrias nacionais Relatório Setorial. São Paulo: Fundunesp. 37 p. 


\section{Macrothink}

Journal of Management Research

ISSN 1941-899X

2012, Vol. 4, No. 4

Schaefer, A. (1997). Consumer knowledge and country of origin effects. European Journal of Marketing, 31, 56-72. http://dx.doi.org/10.1108/03090569710157034

Shimp, T. A., \& Sharma, S. (1987). Consumer ethnocentrism: Construction and validation of the CETSCALE. Journal of Marketing Research, 24, 280-290.

Sharma, S., Shimp, T. A., \& Shin, J. (1994). Consumer ethnocentrism: A test of antecedents and moderators. Journal of the Academy of Marketing Science, 23, 26-37. http://dx.doi.org/10.1177/0092070395231004

Usunier, J. C. (2002). Le pays d'origine du bien influence-t-il encore les évaluations des consommateurs? Revue Française du Marketing, 189/190, 49-67.

Verlegh, P. W. J. (2007). Home country bias in product evaluation: The complementary roles of economic and socio-psychological motives. Journal of International Business Studies, 38, 361-373. http://dx.doi.org/10.1057/palgrave.jibs.8400269

Verlegh, P. W. J., \& Steenkamp, J. B. E. M. (1999). A review and meta-analysis of country-of-origin research. Journal of Economic Psychology, 20, 521-546. http://dx.doi.org/10.1016/S0167-4870(99)00023-9

Verlegh, P. W., Steenkamp, J. B., \& Meulenberg, M. T. (2005). Country-of-origin effects in consumer processing of advertising claims. International Journal of Research in Marketing, 22, 127-139. http://dx.doi.org/10.1016/j.ijresmar.2004.05.003

Yasin, N. M., Noor, M. N., \& Mohamad, O. (2007). Does image of country-of-origin matter to brand equity? Journal of Product \& Brand Management, 16, 38-48. http://dx.doi.org/10.1108/10610420710731142

Zhang, Y. (1996). Chinese consumers'evaluation of foreign products: The influence of culture, product types and product presentation format. European Journal of Marketing, 30(12), 50-68. http://dx.doi.org/10.1108/03090569610153309

Zhang, Y. (1997). Country-of-origin effect: The moderating function of individual difference in information processing. International Marketing Review, 14, 266-287. http://dx.doi.org/10.1108/02651339710173453 